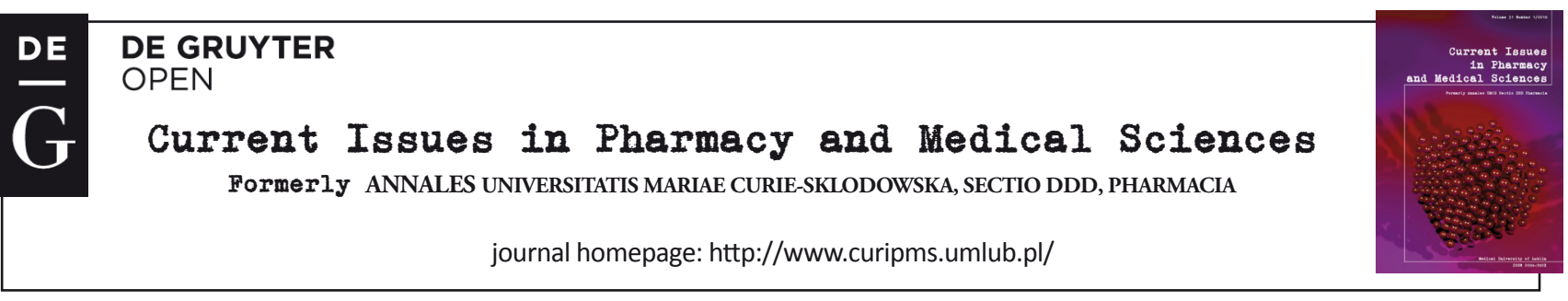

\title{
Frequency of JC virus appearance in the urine of post-transplantation patients
}

\author{
Anastazja Boguszewska, Magdalena Wos, \\ Adrian Jarzynski, Malgorzata Polz-Dacewicz
}

Department of Virology, Medical University of Lublin, ul. Chodzki 1, 20-093 Lublin, Poland

\begin{tabular}{|c|c|}
\hline ARTICLE INFO & ABSTRACT \\
\hline $\begin{array}{l}\text { Received } 29 \text { May } 2017 \\
\text { Accepted } 28 \text { March } 2018\end{array}$ & $\begin{array}{l}\text { Polyomaviruses are common viruses that induce various infections in many mammalian } \\
\text { species, including humans. The best-known viruses of this kind are BKV and JCV. The }\end{array}$ \\
\hline $\begin{array}{l}\text { Keywords: } \\
\text { polyomavirus, } \\
\text { JC virus, transplantation, } \\
\text { bone marrow, } \\
\text { kidney. }\end{array}$ & $\begin{array}{l}\text { aim of the study was to analyze the incidence of infection caused by JCV in a group of } \\
\text { patients after kidney or bone marrow transplant, and to analyze JCV genetic diversity } \\
\text { in post-transplantation recipients. The study group included } 81 \text { patients after kidney } \\
\text { transplantation treated in the Independent Public Teaching Hospital No } 4 \text { in Lublin and } \\
\text { a group of } 24 \text { patients after marrow transplantation from the Children's Clinical Hospital } \\
\text { of Lublin. The research material included } 105 \text { DNA probes from urine samples that } \\
\text { were tested via the PCR method for the presence of JCV genetic material. Amplification } \\
\text { products were separated in agarose gel, positive PCR products were subjected to } \\
\text { purification and the pure product was sent to sequencing. Pearson's chi-square test was } \\
\text { used to investigate the relationship between the prevalence of JCV viruria and study } \\
\text { group and gender. Statistical significance was defined as p }<0.05 \text {. A JCV positive result } \\
\text { was discovered in } 27.6 \% \text { of all samples. In the group of adults, } 34.6 \% \text { were positive, while } \\
\text { in children, this was } 3.4 \% \text {. Among all patients, only } 8 \text { women were infected with the JC } \\
\text { virus, while } 21 \text { men were. We saw that the incidence of infection caused by the JC virus } \\
\text { increases with age. Moreover, JCV DNA is more frequently isolated from men than from } \\
\text { women. JCV infections are also a more common cause of infections in patients after renal } \\
\text { transplantation than in bone marrow transplant patients. }\end{array}$ \\
\hline
\end{tabular}

\section{INTRODUCTION}

The first human polyomavirus was discovered in 1971 from the brain tissue of a patient with Hogkins' lymphoma and progressive multifocal leukoencephalopathy (PML). It was named after the patients initials: John Cunningham. Because polyoma viruses are common global viruses, they cause various infections in many mammalian species, including humans. Fifteen polyomaviruses are currently known. The best-known viruses of this kind are BKPyV and JCPyV [1,2].

In immunocompetent individuals, clinically relevant infections seldom occur, only with a weakened immune system can their reactivation happen. However, primary infections are usually asymptomatic, and it is estimated that more than $80 \%$ of the entire adult population have detectable antibodies against polyomavirus JC [3]. After infection, the viruses persist in the cells for the entirety of life $[3,4]$

\footnotetext{
* Corresponding author

e-mail: anastazja.boguszewska@umlub.pl
}

$\mathrm{JC}$ virus can be detected in nervous and brain tissue, tonsils, lymph nodes, colon, bone marrow, liver, spleen and in other tissues and fluids, including blood, plasma and lymphocytes. This virus is responsible for the formation of progressive multifocal leukoencephalopathy, a disease entailing central nervous system demyelination [5].

JCV genetic material is a double-stranded circular DNA which contains 5130 base pairs. The viral genome is divided into 3 parts: the early coding region, the late coding region and the regulatory region (TCR). The TCR region, located between the early and late coding region, contains regulatory sequences, an origin of replication (ori), enhancers and promoter sequences of the early and late regions. After the virus enters into a nucleus during transcription, $\mathrm{T}$ antigens are products of the early region coding. These are involved in cell preparation for the replication of viral DNA by stimulating the cells to produce the enzymes necessary for replication [6,7]. The JC virus can be found as 7 types 
that are genotypically different. Each type can have several subtypes which differ in genome sequence from 0.5 to $1 \%$. The major continents hold specific JC virus types. Studies have shown that in Europe and America, type 1 is characteristic, type 2 and 7 is notable for Asia, while in Africa, type 3 and 6 are prevalent. These genotypes may differ by about $1 \%$ to $3 \%$ of the sequence. Type 4 resembles type 1 , since there is only a $1 \%$ difference between them. It is characteristic for Germany, Spain and Poland, but particularly for the Basque Country $[4,8,9]$.

The aim of the study was to analyze the incidence of infection caused by JC virus and BK virus in a group of patients after kidney or bone marrow transplant, and to analyze JCV genetic diversity in post-transplantation recipients with reactivation of infection due to JC virus.

\section{MATERIALS AND METHOD}

The study group included 105 patients, 81 after kidney transplantation (adults -41 men and 32 women) treated in the Independent Public Teaching Hospital No 4 in Lublin, and a group of 24 patients (children -7 boys and 17 girls) after marrow transplantation from the Children's Clinical Hospital of Lublin. Among adults, the average age was 47 years and among children, the corresponding figure is 10 years. The research material included DNA isolated from the urine samples obtained from 105 patients during immunosuppressive therapy (Table 1). This research was approved by the Ethics Committee (no KE-0254/133/2013).

Tables 1. Demographics of study group

\begin{tabular}{|c|c|c|c|c|c|c|}
\hline & $\begin{array}{c}\begin{array}{c}\text { Number } \\
\text { of } \\
\text { patients }\end{array} \\
\end{array}$ & $\begin{array}{c}\% \\
\text { of } \\
\text { patients } \\
\end{array}$ & Sex & $\begin{array}{c}\text { Average } \\
\text { age } \\
\text { (years } \\
\end{array}$ & $\begin{array}{c}\text { Age } \\
\text { range } \\
\text { (years) }\end{array}$ & $\begin{array}{c}\text { Type } \\
\text { of } \\
\text { transplant } \\
\end{array}$ \\
\hline \multirow{2}{*}{$\begin{array}{c}\text { Adults } \\
\text { ( }<18 \text { years })\end{array}$} & 49 & $60 \%$ & Male & \multirow{2}{*}{41} & \multirow{2}{*}{$\begin{array}{l}\min .: 19 \\
\max .: 75\end{array}$} & \multirow{2}{*}{ Kidney } \\
\hline & 32 & $40 \%$ & Female & & & \\
\hline \multirow{2}{*}{$\begin{array}{c}\text { Kids } \\
(>18 \text { years })\end{array}$} & 7 & $29 \%$ & Male & \multirow{2}{*}{10} & \multirow{2}{*}{$\begin{array}{c}\min .: 2 \\
\max :: 17\end{array}$} & \multirow{2}{*}{$\begin{array}{l}\text { Bone } \\
\text { marrow }\end{array}$} \\
\hline & 17 & $71 \%$ & Female & & & \\
\hline
\end{tabular}

Urinary isolates were tested via the PCR method for the presence of the genetic material of the JC virus. The size of product was $215 \mathrm{bp}$. The primer sequences are: JLP-155' ACA GTG TGG CCA GAA TTC ACT ACC 3'; JLP-16 5' TAA AGC CTC CCC CCC AAC AGA AA 3'.

All PCR reactions were carried out in the final volume of $20 \mu \mathrm{l}$ using a PCR Core Kit (Qiagen, Hilden, Germany). The reaction mixture included: water for PCR $-11.3 \mu \mathrm{l}$; $10 \times$ bufor PCR with $15 \mathrm{mM} \mathrm{MgCl}-2 \mu \mathrm{l}$; dNTPs $-0.4 \mu \mathrm{l}$; primer JLP-15 - $0.6 \mu \mathrm{l}$; primer JLP-16 - $0.6 \mu \mathrm{l}$; Tag polymerase $-0,1 \mu \mathrm{l}$. The reaction mixture containing $5 \mu \mathrm{l}$ of extracted DNA was amplified in a Sensoquest thermocycler under the following conditions: $95^{\circ} \mathrm{C}$ for $3 \mathrm{~min}$. of initial denaturation then 40 cycles of $94^{\circ} \mathrm{C}$ for $60 \mathrm{~s}$., $62^{\circ} \mathrm{C}$ for $90 \mathrm{~s}$., $72^{\circ} \mathrm{C}$ for $60 \mathrm{~s}$., with final extension at $72^{\circ} \mathrm{C}$ for $10 \mathrm{~min}$. Amplification products are separated in a $2 \%$ agarose gel at $96 \mathrm{~V}$ for about 30 minutes. A DNA band size of $215 \mathrm{bp}$ was observed under UV light.

Positive PCR products, made visible during electrophoresis, were subjected to purification via Amicon Ultra-0.5
(Millipore) column, to remove free dNTPs and the excess of primers. The pure product was sent for sequencing to Genomed, to determine the genotype. Next, a phylogenetic similarity analysis was performed of the obtained strains.

Descriptive statistics were used to characterize patient baseline characteristics. Pearson's chi-square test was used to investigate the relationship between the prevalence of JCV viruria and study group and gender. Statistical significance was defined as $\mathrm{p}<0.05$.

\section{RESULTS}

\section{Occurrence of JCV in the study group}

The study group consisted of 105 DNA probes, positive results were discovered in 29 of them $(27.6 \%)$ and negative results in $76(72.4 \%)$. In the adult group, 34.6\% were positive, while in children's group, $3.4 \%$ were positive. Among all patients, only 8 women were found to be infected with the JC virus, while 21 men were $(\mathrm{p}=0.015)$. A significant association was found between the prevalence of viruria JC and the study group (Table 2).

Tables 2. Prevalence of JCV infections depending on age and gender

\begin{tabular}{|l|c|c|c|c|c|}
\hline \multirow{2}{*}{} & \multicolumn{2}{|c|}{ Positive results } & \multicolumn{2}{c|}{ Negative results } & \multirow{2}{*}{$\mathrm{p}$} \\
\cline { 2 - 5 } & $\mathrm{n}$ & $\%$ & $\mathrm{n}$ & $\%$ & \\
\hline Study group & 29 & 27.6 & 76 & 72.4 & \multirow{2}{*}{$0.003^{*}$} \\
\hline Adults & 28 & 34.6 & 53 & 65.4 & \\
\hline Kids & 1 & 3.4 & 23 & 96.6 & \\
\cline { 1 - 5 } Male & 21 & 37.5 & 35 & 62.5 & \multirow{2}{*}{$0.015^{*}$} \\
\cline { 1 - 4 } Female & 8 & 16.3 & 41 & 83.7 & \\
\hline
\end{tabular}

\section{Sequence analysis of the PCR product}

The JC virus genotypes were identified by way of the PCR product sequence analysis (VP1 gene fragment with the length of $215 \mathrm{bp}$ ) that had been performed in 23 patients. Of the patients who were diagnosed with JC virus reactivation, $91 \%$ had genotype $1 \mathrm{~A}$, while $9 \%$ had $1 \mathrm{~B}$. These genotypes were distinguished through positions 1843 and 1849. Table 3 provides a comparison of the JC virus genotypes sequences derived from infected patients. Depending on the subtype, a prototype sequence was determined which was identifiable at specific positions in the reference sequence of the viral genome. The underlined nucleotides in the prototype sequence enable the distinguishing of $1 \mathrm{~A}$ from the 1B subtype (for 1A, subtype $\mathrm{G}$ occurs at position 1843 , and for $1 \mathrm{~B}$, this is subtype $\mathrm{T}$, while at position 1849 , $\mathrm{A}$ is found for subtype $1 \mathrm{~A}$ and $\mathrm{G}$ for $1 \mathrm{~B})$. The positions in the virus genome which do not affect the genotype type, are underlined.

Tables 3. Differences in the sequences JCV genotypes

\begin{tabular}{|c|c|c|c|c|c|c|c|c|c|c|c|c|c|c|c|}
\hline 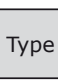 & 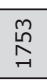 & 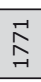 & \begin{tabular}{|l|l} 
\\
$\infty$ \\
-1 \\
-1
\end{tabular} & 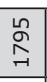 & \begin{tabular}{|l|l} 
\\
0 \\
$\infty$ \\
-1 \\
\end{tabular} & $\stackrel{\infty}{\rightarrow}$ & $\underset{\substack{\infty \\
-1}}{\mathbb{N}}$ & $\begin{array}{l}0 \\
\infty \\
\infty \\
\sim\end{array}$ & $\underset{\substack{\infty\\
}}{\widehat{N}}$ & $\stackrel{m}{q}$ & 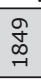 & $\begin{array}{l}0 \\
\text { L } \\
\infty \\
-1 \\
-1\end{array}$ & $\vec{n}$ & ติ & $\underset{\infty}{\infty}$ \\
\hline & $A$ & & ( & & & & & & & & & A & & & $\mathrm{G}$ \\
\hline & A & & & & 1 & & & 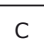 & & & & & & & \\
\hline
\end{tabular}




\section{DISCUSSION}

JC virus is becoming more widespread in the world's population, and it can bring about dangerous kidney infection that can lead to progressive multifocal leukoencephalopathy, characterized by demyelination of the nerve tissue of the nervous system $[10,11]$.

In this study, JCV was detected in $27.6 \%$ of all test patients. Other studies of transplant patients and normal population have observed a JCV prevalence between 9.5-38\% $[12,13,14]$. Indeed, Boukoum et al. [13] detected JCV viruria in $13 \%$ of all healthy individuals, but in $38 \%$ of all kidney transplant recipients in their test population. In Saundh et al. [14], JCV was indicated in 15 of 112 cases (13.3\%). There was no significant differences observed between control and study groups. Boukoum et al. [12] in their analysis of occurrence polyomaviruses, noted that JCV was detected in $9.5 \%$ of all urine samples, whereas JCV was not detected in plasma.

Kmieciak et al. [9] in their studies on the prevalence of the JCV DNA load in normal donors, showed an increase of infection with age. They carried out their tests utilizing the PCR method by amplifying a fragment of $215 \mathrm{bp}$ from the region of the VP1 protein gene. On examining a Polish group of 113 people, they saw that $46 \%(52 / 113)$ of the test population were infected with the JC virus. Moreover, most infections were detected in people older than 60 years $(63.6 \%)$, which may indicate possible reactivation of the virus in the later period of life when the human body, even in healthy people, is already weakened. Furthermore, through determining the JCV genotype by analysis of the VP1 gene fragment sequence obtained from infected persons, they showed a significant prevalence of subtype $1 \mathrm{~A}-59.6 \%$ $(31 / 52)$, while the second most prevalent genotype was $1 \mathrm{~B}$ $-25 \%(13 / 52)$, the third was $2 \mathrm{C}-11.5 \%(6 / 52)$, and the fourth was $2 \mathrm{~A}-3.8 \%(2 / 52)$.

Such incidence and distribution of JCV genotypes in the Polish population confirms the fact that in European countries, including Poland, genotype 1 is the one most common. The results obtained by Kmieciak et al. are similar to that obtained in this study, where the 1A genotype subtype prevailed. Their study, however, did not see genotype 4, although it is the second most common in Europe. This result may be due to the geographical area from which the test samples came.

In comparing incidence of infection, Kmieciak et al. reported that $46 \%$ of all healthy donors were infected, while the results obtained in our research showed a lesser virus load detection $-27.6 \%$. This may be related to a smaller number of samples from people over 61 years of age (12 persons) than in the above mentioned study (22 persons). Due to the possibility of JCV infection in childhood (almost $80 \%$ of the world's population is infected), when the infection can pass without symptoms, but anti-JCV antibodies are produced, which indicate an infection, the virus remains in a latent form. With decreased immunity, it can be reactivated and engender PML. The detection of viral DNA in the urine can occur not only during the disease, but also during other viral infections or during pregnancy. These effects could explain the very high detection of JCV DNA in healthy subjects by Kmieciak et al. [9].

The low incidence of JCV infections in children (4\%) can be observed in the analysis of the tests carried out on samples from patients hospitalized due to a bone marrow transplant. This effect is confirmed by research conducted by Agostini et al. [15], Kmieciak et al. [9] and Dubois et al. [16]. This can be explained by the young age of the patients (the average age of this study subjects was 10 years). Indeed, the majority of such children have not yet had contact with the JCV virus, therefore, virus reactivation does not occur after administration of immunosuppressive drugs. This hypothesis can be checked via additional research on the anti-JCV antibodies prevalence.

Agostini et al. 2001 [15] conducted a survey on a group of 350 patients from four countries, including Poland, assessing JCV genotype kind and the incidence of JC virus infection. The study groups included adults aged 13-95 - 191 women and 159 men. Patients from Poland accounted for 59 of these individuals - of which $52 \%$ were male (29/56) and $48 \%$ were female (27/56). Using the PCR method with primers JLP-15 and JLP-16, they detected the JCV DNA load, and then they conducted a sequencing of the products obtained to determine the genotype of the detected virus. Of 350 respondents, JCV infection was detected in 153 , which represents $44 \%$ of the study population. With regard to the Polish patients alone, the JCV DNA load was detected in 22 patients, which in relation to the Polish study group, gives a figure of $39 \%(22 / 56)$. After the analysis of the genotypes, a clear dominance of type 1 was observed, in that $1 \mathrm{~B}$ subtype had prevalence $(62 / 153)$ over $1 \mathrm{~A}(53 / 153)$, while the remaining genotypes were obtained in following quantities: 33 of subtype 4 (33/153), 3 subtypes 2B (3/153), 1 subtype 2A (1/153) and 1 subtype $3 \mathrm{~A}(1 / 153)$. Referring to the Polish group alone, $1 \mathrm{~A}$ subtype of the virus was the most prolific $(11 / 56)$, then 1B (7/56) and subtype $4(4 / 56)$. The research revealed the significant preponderance of JC virus genotype 1 in Europe, thus, in Poland [15].

Our study is also indicative of the predominant occurrence of type 1 in Poland. The proportion of genotype 1A received in the examined subjects was $91 \%$, which is almost twice higher than the incidence of this genotype in the Polish group studied by Agostini et al. [15], where the proportion was $50 \%$. Among the sequences analyzed, the $1 \mathrm{~B}$ subtype represented $9 \%$, and the incidence of JC virus infection was $27.6 \%$ of all the patients tested, which in respect of the results presented above (39\%), indicates a worrisome degree of JCV infection among hospitalized patients.

A similar probability of virus migration was demonstrated by Agostini et al. [7]. They conducted a study which compared the genotypes of JC virus in groups of indigenous people in Navajo, Flathead and Chamorro. The three studied populations are ethnic groups from Asia (dating back many thousands of years) and are recognized as Native Americans. Using the PCR method, the researchers revealed the presence of JCV DNA load in $66 \%$ of all the Navaho, 
$65 \%$ of all the Flathead and $69 \%$ of all the Chamorro people. After further analysis of the viral DNA by sequencing, they were able to identify individual genotypes. The vast majority: $56-68 \%$ of all JCV strains obtained from the three populations belongs to the Asian genotype - $2 \mathrm{~A}$.

The fact that the main type of JC virus occurring in the United States represents genotype 1 (European), while 2A and $2 \mathrm{~B}$ originate from Asia, suggests that the prevalence of genotype 2A among Native Americans has an Asian origin. This would indicate that infection of the US population with JC virus occurred earlier than did Native American contact with the population from Europe, and that it precedes the [modern time] migration of these people from Asia to America. Because the virus strains as infectious diseases, move within particular social groups through their mass movement, they allow the tracking of human migration patterns around the world. This is a confirmation of the fact that $\mathrm{JC}$ virus is a good marker of current and prehistoric human migration [17].

Moreover, the polyomavirus has evolved relatively rapidly in comparison with the human genome, but slowly, in contrast to the infectious RNA viruses, and, therefore, is more applicable as a marker. Of note, the essence of a good quality migration marker is its genetic stability, which is typical for JCV as a DNA virus $[10,17]$.

\section{CONCLUSIONS}

The incidence of infection caused by the JC virus increases with age. JCV DNA is more frequently isolated from men than from women. JCV infections are more common causes of infections in patients after renal transplantation than in bone marrow transplant patients. Virus genotype 1 alone occurred in the study population, with a significant dominance of subtype $1 \mathrm{~A}$ over $1 \mathrm{~B}$, which confirms that genotype 1 is the most common in Europe.

\section{REFERENCES}

1. Barth H, Solis M, Lepiller Q, Sueur C, Soulier E, Caillard S, et al. 45 years after the discovery of human polyomaviruses BK and JC: Time to speed up the understanding of associated diseases and treatment approaches. Crit Rev Microbiol. 2017;43(2):178-95.
2. Delbue S, Ferraresso M, Ghio L, Carloni C, Carluccio S, Belingheri $\mathrm{M}$, et al. A review on JC virus infection in kidney transplant recipients. Clin Dev Immunol. 2013; ID92639.

3. Antonsson A, Green AC, Mallitt KA, O'Rourke PK, Pawlita M, Waterboer T, et al. Prevalence and stability of antibodies to the BK and JC polyomaviruses: a long-term longitudinal study of Australians. J Gen Virol. 2010;91:1849-53.

4. Jiang M. Abend JR, Johnson SF, Imperiale MJ. The role of polyomaviruses in human disease. Virology. 2009;384:266-73.

5. Krumbholz A, Bininda-Emondsb O, Wutzlera P, Zella R. Phylogenetics, evolution, and medical importance of polyomaviruses. Infect Genet Evol. 2009;9:784-99.

6. Beltrami S, Gordon J. Immune surveillance and response to JC virus infection and PML. J Neurovirol. 2014;20(2):137-49.

7. Boothpur R, Brennan DC. Human polyoma viruses and disease with emphasis on clinical BK and JC. J Clin Virol 2010;47:306-12.

8. Hirsch HH, Knowles W, Dickenmann M, Passweg J, Klimkait T, Mihatsch MJ, et al. Prospective study of polyomavirus type BK replication and nephropathy in renal-transplant recipients. N Engl J Med. 2002;347:488-96.

9. Kmieciak D, Dębicki S, Trzeciak WH. Occurrence rate and genotype distribution of the JC virus (JCV) in a sample from the Polish population. J Medical Virol. 2008;80:1079-83.

10. Dalianis T., Hirsch H.: Human polyomaviruses in disease and cancer. Virology. 2013;437(2):63-72.

11. Ferenczy MW, Marshall LJ, Nelson CD, Atwood WJ, Nath A, Khalili $\mathrm{K}$, et al. Molecular Biology, Epidemiology, and Pathogenesis of Progressive Multifocal Leukoencephalopathy, the JC Virus-Induced Demyelinating Disease of the Human Brain. Clin Microbiol Rev. 2012;25(3):471-506.

12. Boukoum H, Nahdi I, Sahtout W, Skiri H, Aloui S, Achour A, et al. $\mathrm{BK}$ and JC polyomavirus infections in Tunisian rental transplant recipient. J Medical Virol. 2015;87:1788-95.

13. Boukoum H, Nahdi I, Sahtout W, Skiri H, Segondy M, Aouni M. BK and JC virus infections in healthy patients compared to kidney transplant recipients in Tunisia. Microb Pathog. 2016;97:204-8.

14. Saundh BK, Baker R, Harris M, Hale A. A prospective study of renal transplant recipients reveals an abscenceof primary JC polyomavirus infections. J Clin Virol. 2016;77:101-5.

15. Agostini HT, Yanagihara R, Davis V, Ryschkewitsch CF, Stoner GL. Asian genotypes of JC virus in Native Americans and in a Pacific Island population: markers of viral evolution and human migration. Proc Natl Acad Sci. 1997;94:14542-6.

16. Dubois V, Moret H, Lafon ME, Brodard V, Icart J, Ruffault A, et al. JC virus genotypes in France: molecular epidemiology and potential significance for progressive multifocal leukoencephalopathy. J Infect Dis. 2001;183(2):213-17.

17. Agostini HT, Deckhut A, Jobes DV, Girones R, Schlunck G, Prost MG, et al. Genotypes of JC virus in East, Central and Southwest Europe. J Gen Virol. 2001;82:1221-31. 